\title{
Do Economic Adjustment Programmes Set Conflicting Objectives? The Case of Greece
}

\author{
Panagiotis Liargovas, Marios Psychalis \\ Department of Economics, University of Peloponnese, Tripolis, Greece \\ Email: liargova@uop.gr,mpsychalis@uop.gr
}

How to cite this paper: Liargovas, P. and Psychalis, M. (2019) Do Economic Adjustment Programmes Set Conflicting Objectives? The Case of Greece. Theoretical Economics Letters, 9, 3065-3087. https://doi.org/10.4236/tel.2019.98188

Received: November 8, 2019

Accepted: December 27, 2019

Published: December 30, 2019

Copyright $\odot 2019$ by author(s) and Scientific Research Publishing Inc. This work is licensed under the Creative Commons Attribution International License (CC BY 4.0).

http://creativecommons.org/licenses/by/4.0/

(c) (i) Open Access

\begin{abstract}
Certain EU countries could not counter the effects of the 2008 global financial crisis. As a result, they lost access to international markets. The EU attempted to resolve the European financial crisis by implementing economic adjustment programmes. Economic adjustment programmes included financing conditional on the implementation of reforms. All programmes consisted of three main pillars: Fiscal consolidation, financial stability, and promoting growth and competitiveness. This article examines whether the objectives set under each pillar were in conflict with or complementary to the objectives set under other pillars. Studying the case of Greece, it is concluded that certain economic adjustment programme objectives and policies were indeed conflicting, rendering their implementation harder.
\end{abstract}

\section{Keywords}

Economic Adjustment Programmes, Greek Crisis Reforms, Fiscal Financial and Competitiveness Policy

\section{Introduction}

Economic Adjustment Programmes (EAPs) were not known in the EU. They are usually implemented in developing economies, producing questionable results, while they seem to have a negative impact on social policy [1] [2] [3] $]^{1}$, as was the case in Greece [4] [5] [6]. Literature is divided on the effectiveness of economic adjustment programmes. Academics argue that EAPs have failed, while the institutions implementing them, such as IMF [7], the European Commission [8] [9] and OECD [10], argue that EAPs have achieved their main objectives but require improvements [11] [12].

Specifically, it is argued that economic adjustment programmes did not man${ }^{1}$ In literature they are called "economic structural adjustment programmes (ESAPs)". 
age to assist Greece in overcoming the financial crisis, while their objectives were not met [13]. Regarding the failure in meeting objectives, it is noted that official forecasts were over-optimistic, predicting rapid recovery [14]. The failure of EAPs in Greece came as the result of both domestic factors, such as the functioning of the public sector and shadow economy, and external factors, such as the lack of alternative economic policy tools and oversights of the programmes [15]. Moreover, the implementation of austerity programmes not only did not improve the credibility of public finances in international money markets, but instead it further damaged credibility, resulting in increased speculation on sovereign bonds [16] and an increase in the Debt/GDP ratio for periphery countries [17]. In contrast to Greece, Portugal managed to regain access to markets much faster, as fewer austerity measures were implemented, exports increased at a faster pace and there was consent on political level [18]. Cyprus lost merely 5\% of its GDP, compared to Greece losing 22\%, as Cyprus suffered a smaller crisis and accelerated the implementation of the programme. Yet both countries continue to face significant issues, such as high public debt and NPLs [19]. Moreover, when defining fiscal adjustment, both short-term cost and long-term benefits should be considered. Special emphasis should be placed on designing consolidating packages that consist of well-planned adjustments that could faster stabilise the debt ratio [20], as the EAP failure or success depends on domestic policies and economic circumstances [21]. To sum up, EAPs have a negative impact on economy due to austerity as fiscal consolidation has higher cost for GDP during a recession [22], but they are also linked to positive structural reforms [23]. Based on the reports prepared by international organisations, such as OECD, IMF, World Bank, ECB, ESM and the European Commission, the main objectives for Pillar I, fiscal consolidation, are the following.

1) Public debt as a percentage of GDP;

2) Total government revenue in million EUR;

3) Total government expenditure in million EUR;

4) Fiscal balance as a percentage of GDP.

These ratios are constantly used as a measure to evaluate the implementation of the fiscal consolidation reforms in all economic adjustment programmes and in all reviews.

The main objectives for Pillar II, financial stability are the following.

1) NPLs as a percentage of total lending;

2) Interest rate of 10-year government bond;

3) Growth rate of new loans;

4) Bank deposits.

Finally, the main objectives for Pillar III of Pillar III, promoting competitiveness are the following.

Main objectives for promoting competitiveness:

1) Growth rate;

2) Unit labour cost;

3) Current account balance in million EUR; 
4) Foreign direct investment in million EUR;

5) Unemployment rate.

For an economy to be effective, all pillars should function together. In other words, fiscal policy can contribute to improving ratios, for example decreasing unemployment rates, when coordinated closely not only with monetary policy but also with financial stability policies [24].

Finally, it is mentioned that Sections 4 - 6 are closely connected, as each section examines the relationships between the ratios under a given Pillar and the ratios under the other two Pillars. Specifically, in our research, the ratios under each Pillar constitute the dependent variable for a given section and the independent variable for the other two sections. Therefore, the ratios rotate between dependent and independent variables.

\section{Methodology}

Descriptive statistics, panel data analysis and ordinary least squares (OLS) were employed to examine relationships between the main objectives of the three pillars of the economic adjustment programmes, so as to answer the research question. The main objectives were selected according to the emphasis placed on them by the European and international institutions when evaluating the reforms of the three strategic pillars. We employed descriptive statistics to illustrate an overview and the development of the indicators and relationships under examination. That is, we considered whether the indicators under examination increase, decrease or remain stable. We employed panel data analysis to examine the correlation between the variables under examination. The correlation between the variables reflects the degree of linear relationship between two variables. Lastly, we employed ordinary least squares to examine the relationships between the variables under examination, monitoring whether independent variables affect dependent variables. All these tools allow us to have a complete overview of the variables under examination.

\section{Literature Review}

Literature is divided on the effectiveness of PEA -Programmes of Economic Adjustment or SAP-Structural Adjustment Programmes [25] [26]. Meanwhile, research literature has focused on developing economies, with emphasis on countries in Africa, Asia and Latin America.

On the one hand, PEAs may destabilise growth [27], and, despite their necessity, they have not been effective [28]. Moreover, the policies planned under SAPs have several weaknesses [29]. The implementation of SAPs results in rising unemployment and deterioration of other socio-economic indicators [30] [31]. SAPs should strive for sustainability, rather than economic liberalization [32], and conditionality policies and measures of SAPs should be reviewed [33], as they have important political consequences [34]. Lastly, prerequisites imposed on such programmes by the IMF represent the major obstacle to economic 
growth [35] and despite achieving fiscal outcomes in certain cases, they do not allow the private sector to grow [36].

On the other hand, it is argued that PEA and SAP policies, such as increasing private investment as a percentage of GDP, decreasing the fiscal deficit and improving the current account balance, foster growth [37] [38], while PEAs should be accompanied by debt relief measures [39], and fiscal consolidation improves consumer expectations and growth [40]. Moreover, international pressure, as well as the cost of non-compliance, drives countries under PEA to adopt structural reforms [41] [42]. Lastly, it is noted that SAPs can bring positive outcomes, for example Ghana's economic miracle [43], yet their success depends on each country's circumstances [44].

\section{The Relationship between Fiscal Consolidation and Financial Stability}

\section{Public Debt and Financial Support}

Monitoring public debt as a percentage of GDP was a main objective for fiscal consolidation ${ }^{2}$. Nonetheless, the debt to GDP ratio may deteriorate during a crisis, as a result of the interaction between the banking system and public finances [45]. Therefore, the increase in public debt is at large explained by the extraordinary measures taken to support the financial sector, revealing a major interaction between the fiscal and financial sectors [46].

The decrease in deposits, the increase in NPLs, the decrease in the banks' assets and PSI led Greek banks in need of a recapitalisation $[47]^{3}$, resulting in the increase of public debt [48], as Table 1 shows.

Figure 1 confirms that during the crisis public debt as a percentage of GDP increased from 109\% to 181\%, bank deposits decreased from 235 billion EUR to 152 billion EUR, NPLs increased from 14 billion EUR to 81 billion EUR, and bank assets decreased from 464 billion EUR to 292 billion EUR. Table 2 shows how an increase in the NPL rate by 1 basis point increases public debt by $0.79 \%$, and how an increase in the change rate in new lending by 1 basis point decreases public debt as a percentage of GDP by $2.24 \%$.

Table 3 presents the correlations between the objectives set under Pillar I and Pillar II. The increase in NPLs and in the GGB interest rate is positively correlated to the increase in public debt, whereas the growth rate of new loans and the change in bank deposits are negatively correlated to the increase in public debt.

\footnotetext{
${ }^{2}$ During the third programme, a new objective (milestone) was added: Gross Finance Needs (GFN)/Debt [90]. GFN includes the debt structure, such as maturity, interest rates and interest deferrals [87]. In the author's opinion, it becomes clear that it would be impossible to decrease public debt at EU average, i.e. at $86.1 \%$ (Eurostat, 2019), or at IMF target (85\%) or at the target set in the Founding treaties (60\% of GDP) in the medium term.

${ }^{3}$ It has been argued that if it was not for the PSI, the government would not need to participate in the recapitalisation of the banks [85]. As a result of the PSI, the banks incurred losses that reached 37.7 billion EUR and their total losses were equal to $78 \%$ of the nominal value of the Greek Government Bonds [47]. During the crisis, 14 banks were restructured and the number of banks was decreased by $40 \%[88]$.
} 
Table 1. Recapitalisation cost of greek banks.

\begin{tabular}{cccc}
\hline Year & Public sector & Private sector & Total \\
\hline June 2013 & 25.5 & 3 & 28.5 \\
May 2014 & 0 & 8.3 & 8.3 \\
Dec 2015 & 5.4 & 9 & 14.4 \\
Total & 30.9 & 20.3 & 51.2 \\
\hline
\end{tabular}

Source: Bank of Greece.

Table 2. Public Debt \% GDP regression.

\begin{tabular}{ccccc}
\hline \multicolumn{5}{c}{ Dependent Variable: Public Debt \% GDP } \\
\hline \multicolumn{4}{c}{ Sample: } & 2004-2018 - Included observations: 15 after adjustments \\
\hline Variable & Coefficient & Std. Error & t-Statistic & Prob \\
\hline C & 1.366662 & 0.111869 & 12.21662 & 0.0000 \\
NPL \% total lending & 0.797533 & 0.315928 & 2.524417 & 0.0267 \\
New lending rate & -2.244032 & 0.691082 & -3.247130 & 0.0070 \\
R-squared & 0.927935 & Mean dependent var & 1.467653 \\
Adjusted R-squared & 0.915924 & S.D dependent var & 0.336774 \\
S.E of regression & 0.097651 & Akaike info criterion & -1.637985 \\
Sum squared resid & 0.114428 & Schwarz criterion & -1.496375 \\
F-statistic & 77.25784 & Durbin-Watson stat & -1.385879 \\
Prob (F-statistic) & 0.000000 & & \\
\hline
\end{tabular}

Table 3. Indicators correlations.

\begin{tabular}{ccccc}
\hline & NPL rate & GGB rate & New Banking rate & Deposits in bn \\
\hline Public Debt Rate & 0.939223 & 0.335385 & -0.93799 & -0.47832 \\
Total Gov. Revenue & 0.169791 & 0.20469 & 0.072979 & 0.697735 \\
Total Gov. Spending & -0.29044 & 0.236929 & 0.32355 & 0.901962 \\
Fiscal Balance & 0.586081 & 0.236929 & -0.38655 & -0.8078 \\
\hline
\end{tabular}

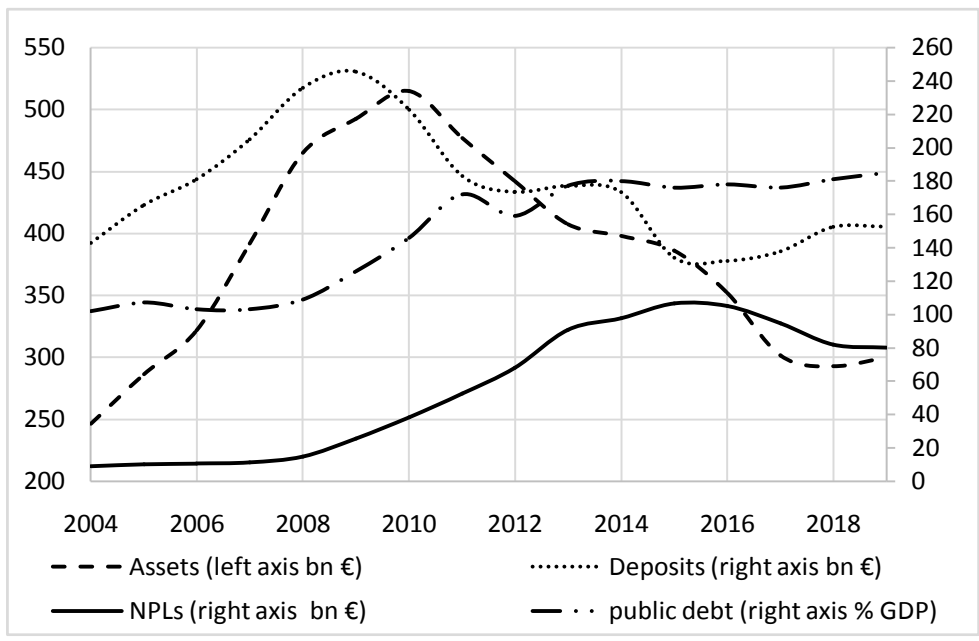

Figure 1. Bank Assets, NPLs, Deposits and public debt between 2004 and 2019. Source: Bank of Greece. 
NPLs and GGB are positively correlated to fiscal balance, whereas the growth rates of new loans and deposits are negatively correlated to fiscal balance. Accordingly, NPLs are negatively correlated to total government expenditure, whereas GGB, growth rate of new loans and bank deposits are positively correlated to total government expenditure. Total government revenue is positively correlated to all objectives set under Pillar II. Therefore, it becomes apparent that 10 out of 16 relationships are in conflict, which means that improvements in a certain objective have a negative impact on the outcome of the correlated objective.

\section{The Relationship between Financial Stability Objectives and Objectives for Promoting Competitiveness}

\subsection{Non-Performing Loans}

Decreasing NPLs was a major objective for bank resolution. NPLs are positively correlated to unemployment, whereas they are negatively correlated to GDP growth rate and inflation [49]. Furthermore, NPLs are positively correlated to macroeconomic and financial disequilibriums, as well as to the government's fund-raising capacity [50]. Figure 2 confirms that during the crisis, NPLs in Greece increased from $5.7 \%$ to $45.4 \%$ of total lending, unemployment increased from $7.76 \%$ to $26.49 \%$, GDP decreased from 241 billion EUR to 180 billion EUR and there was also deflation. Also, NPLs are negatively correlated to return on bank assets and positively correlated to the real interest rate and the loan loss reserves to total loans ratio [51]. Moreover, NPLs negatively affect the growth rate of new loans as a result of the increased credit risk [52], whereas it has been observed that when the growth rate of new loans increases, NPLs increase too [53]. In Greece, the increase in NPLs resulted from the increase in unemployment and the decrease in economic activity, while theories regarding aggressive lending policies and credit expansion to customers of lower credit quality were not validated [54].

In the author's opinion, NPLs in Greece are negatively correlated to the development of the property price index. Literature has not examined such hypothesis. Figure 3 confirms that, during the crisis, NPLs increased, financing rate decreased, the real interest rate increased from $2.45 \%$ to $6.41 \%$, and the property price index decreased from 100.93 to 56.23 . Last, it has been argued that the increase in the GDP growth rate leads to a decrease in NPLs [55].

\subsection{Growth Rate of New Loans}

The increase in the growth rate of new loans decreases unemployment ${ }^{4}$ [56], whereas tightening up lending leads to slower growth rates, fewer new job openings, higher unemployment and increased inequality. In other words, slow growth rates of new credit lowers welfare [57]. Figure 4 confirms that during the

${ }^{4}$ Banks assess, price and integrate unemployment insurance cost in their interest rates [86]. On the other hand, state unemployment insurance (state UI) decreases deposits, resulting in a decrease in investment and in the growth rate of new loans [89]. 


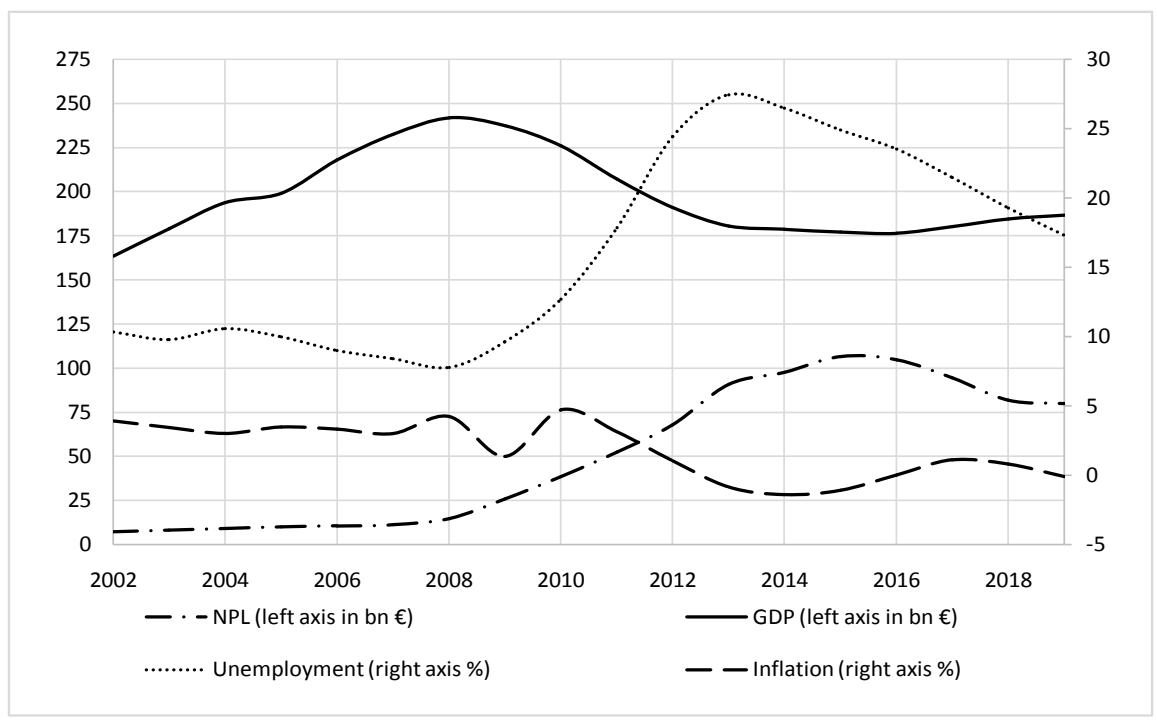

Figure 2. NPLs, GDP, Unemployment and inflation. Source: Bank of Greece and Eurostat.

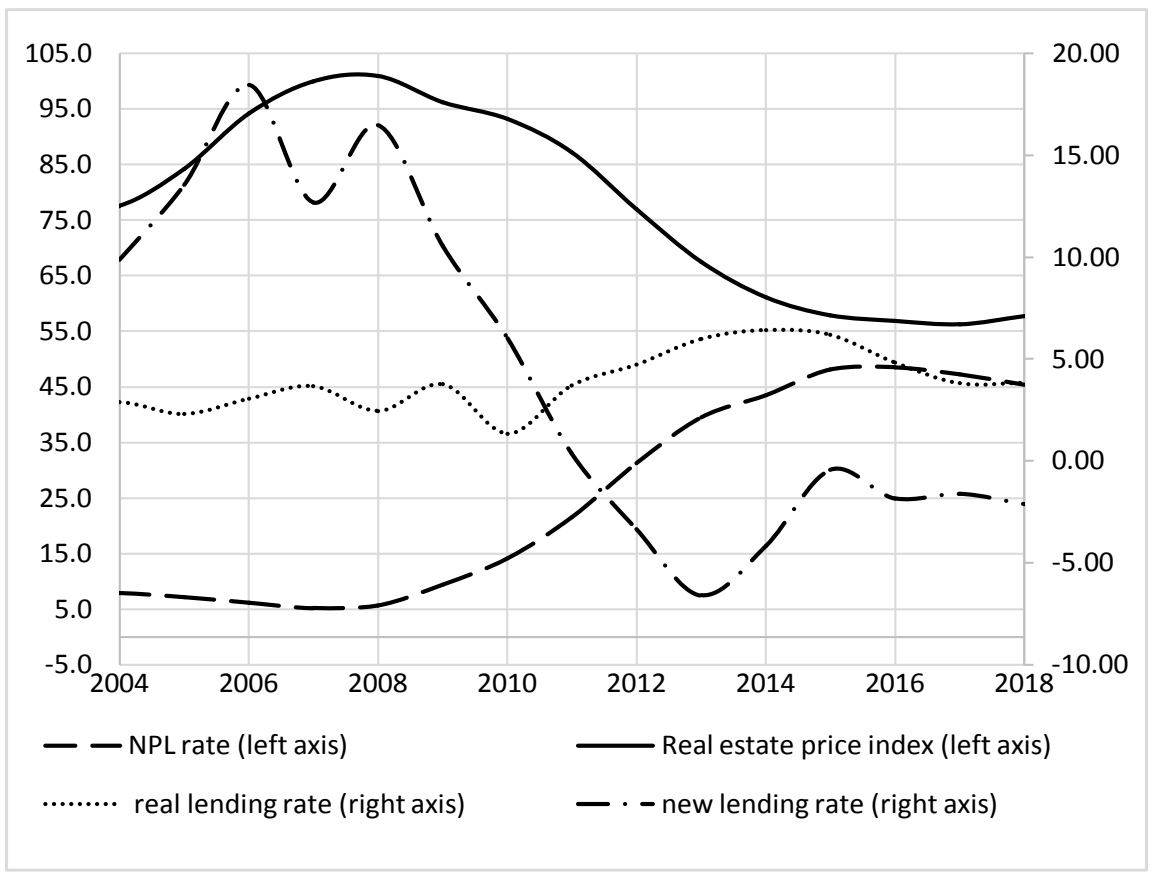

Figure 3. NPLs, Real landing, Real estate, New Lending. Source: Bank of Greece.

crisis the change rate of lending decreased, unemployment increased and growth rate decreased. Table 4 shows that an increase in the growth rate of new loans by 1 basis point decreases NPLs by $1.95 \%$.

Table 5 presents how growth rate and FDI are negatively correlated to NPLs and GGBs, whereas unemployment, ULC and BoP are positively correlated to NPLs and GGBs. Likewise, ULC is positively correlated to the growth rate of new loans and bank deposits, whereas BoP, FDI and unemployment are negatively correlated to the growth rate of new loans and bank deposits. Last, 


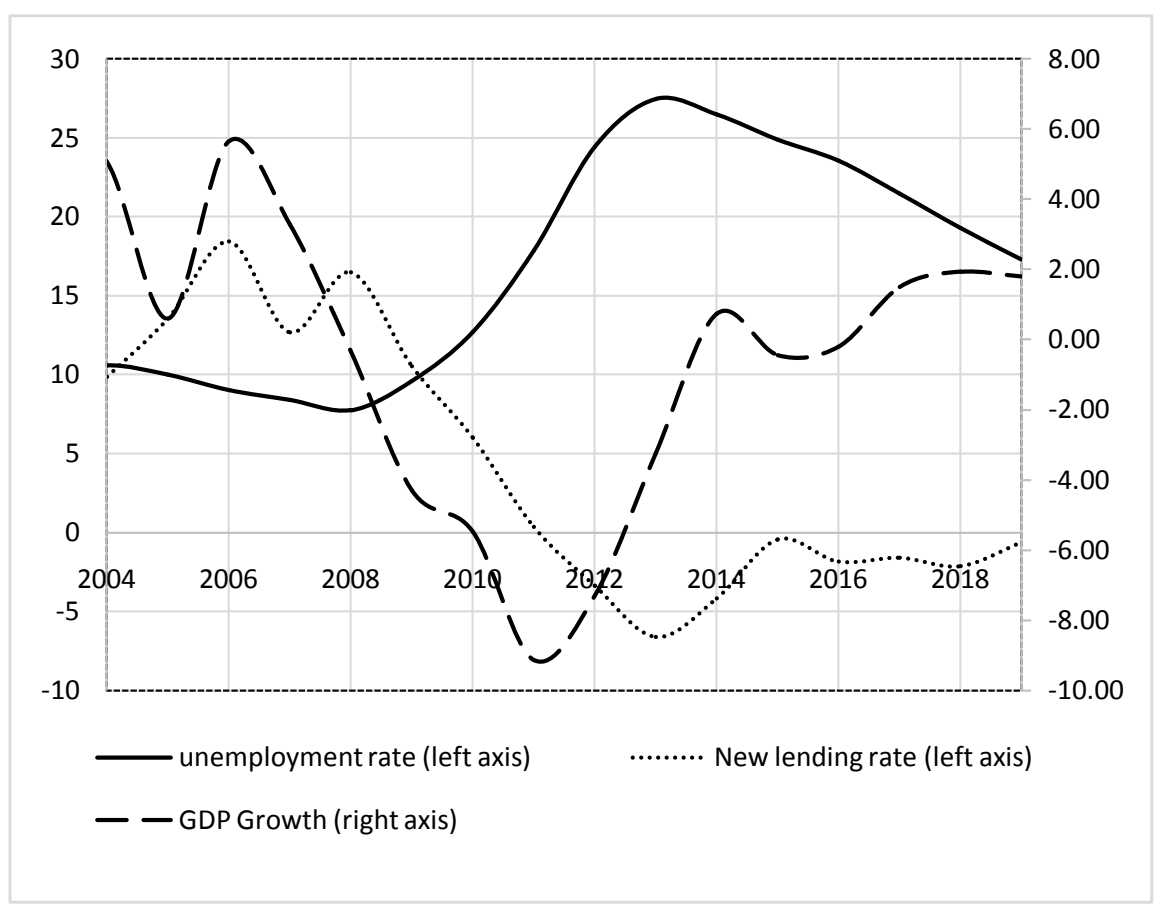

Figure 4. Unemployment, new lending and GDP. Source: Bank of Greece and Eurostat.

Table 4. NPL \% total lending regression.

Dependent Variable: NPL \% total lending

Method: OLS

Sample: 2004-2018

Included observations: 15 after adjustments

\begin{tabular}{ccccc}
\hline Variable & Coefficient & Std. Error & t-Statistic & Prob \\
\hline C & 0.342080 & 0.025368 & 13.48470 & 0.0000 \\
New lending rate & -1.951469 & 0.274112 & -7.119228 & 0.0000 \\
R-squared & 0.795865 & Mean dependent var & 0.253848 \\
Adjusted R-squared & 0.780163 & S.D dependent var & 0.182837 \\
S.E of regression & 0.085727 & Akaike info criterion & -1.951741 \\
Sum squared resid & 0.095538 & Schwarz criterion & -1.857334 \\
Log likehood & 16.63805 & Hannan Quinn criter. & -1.952746 \\
F-statistic & 50.68341 & Durbin-Watson stat & 0.689513 \\
Prob (F-statistic) & 0.000008 & &
\end{tabular}

Table 5. Indicators correlations.

\begin{tabular}{cccccc}
\hline & GDP Growth rate & ULC & BoP & FDI & Unemployment rate \\
\hline NPL rate & -0.22655 & 0.149159 & 0.828032 & -0.3293 & 0.900236 \\
GGB rate & -0.74851 & 0.375218 & 0.232772 & -0.25122 & 0.490552 \\
New Banking & 0.407694 & 0.236929 & -0.83799 & -0.25122 & -0.93972 \\
Lending rate & & & & & -0.56112 \\
Deposits in bn & -0.33472 & 0.626346 & -0.81863 & -0.25122 & \\
\hline
\end{tabular}


growth rate is positively correlated to the growth rate of new loans, whereas it is negatively correlated to bank deposits. Eleven out of twenty relationships are in conflict.

\section{The Relationship between Objectives for Promoting Competitiveness and Fiscal Consolidation Objectives}

This section explains the relationship between competitiveness indicators and fiscal consolidation objectives. Specifically, it considers current account balance, twin deficits and fiscal multiplier as the dependent variables, indicators reflecting competitiveness and growth.

\subsection{Current Account Balance}

Promoting competitiveness mainly through implementing reforms that would improve the current account balance was a major objective set under the EAPs [58]. Literature heavily criticizes this hypothesis.

It has been argued that the current account balance does not constitute a measure for evaluating competitiveness [59], whereas disequilibriums in current account balance do not relate to the Euro crisis [60]. Moreover, the dynamics of the current account balance relates to unit labour cost (ULC) [61] and imports but not to exports [62]. Figure 5 and Figure 6 confirm that the current account balance moves in the opposite direction than the unit labour cost. The improvement in the current account balance from a deficit of 36 billion EUR in 2008 to a deficit of 5.3 billion EUR in 2018 is due to the increase in exports from 56 billion EUR to 69 billion EUR and the decrease in imports from 84 billion EUR to 72 billion EUR during the said period.

Table 6 shows how an increase of the ULC by 1 basis point decreases BOP by 246 million EUR, whereas an increase of the imports by 1 million EUR decreases

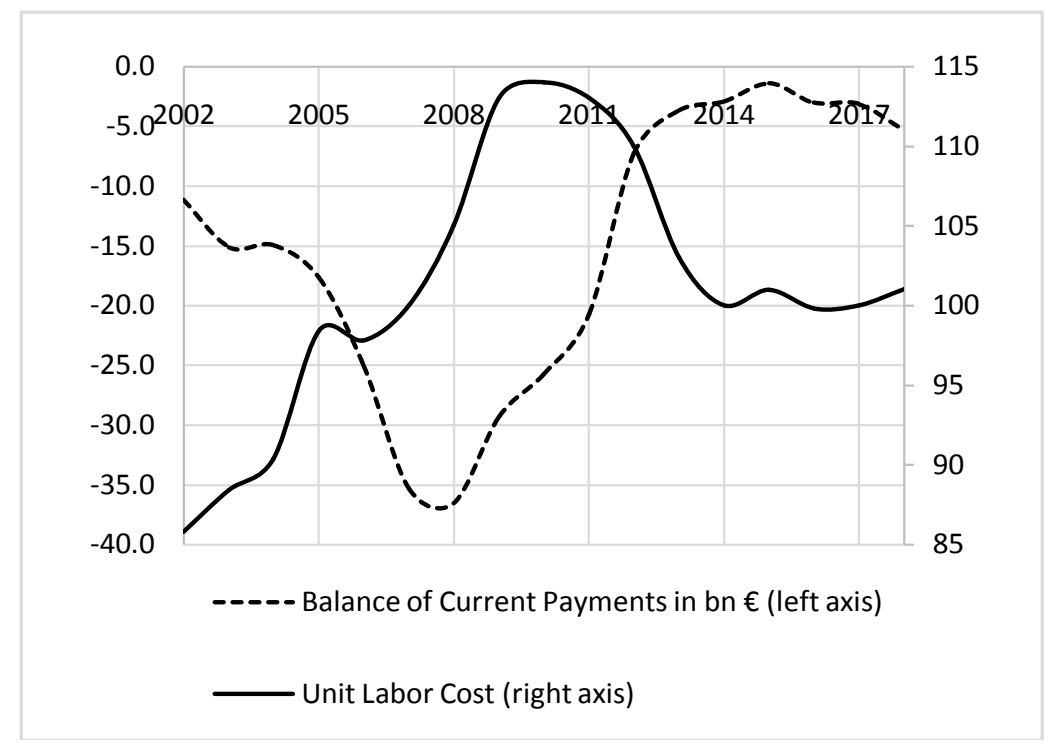

Figure 5. BOP and ULC. Source: Bank of Greece. 


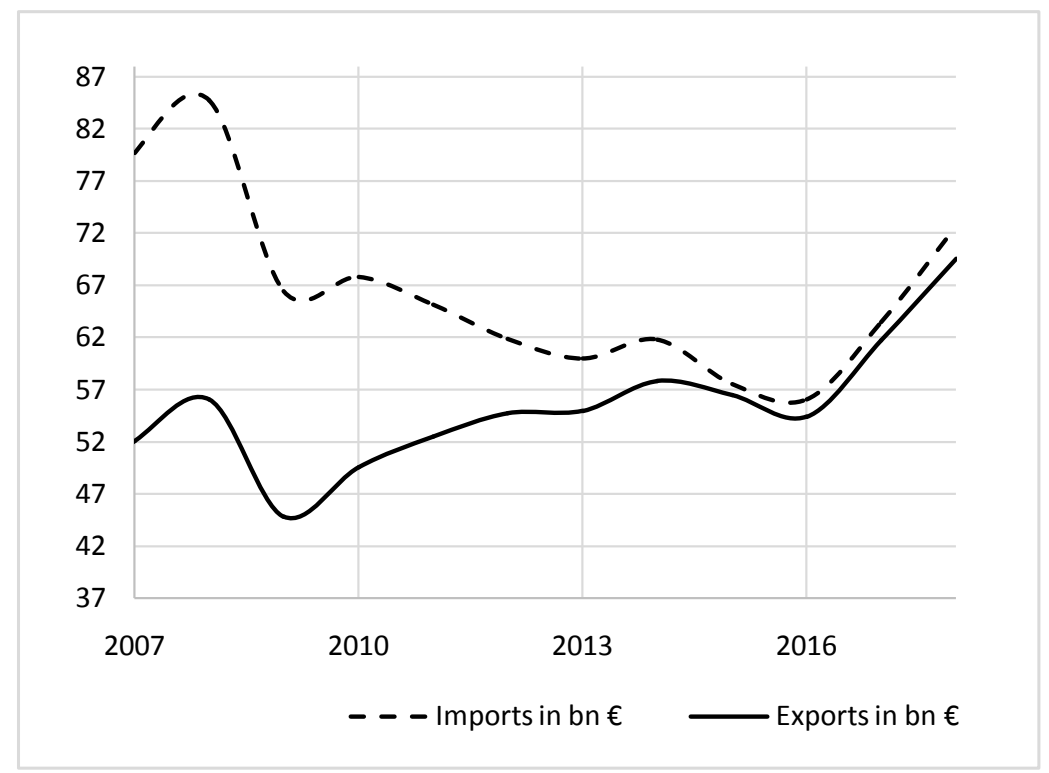

Figure 6. Imports and exports. Source: Bank of Greece.

Table 6. BOP regression.

Dependent Variable: Balance of Payments

Sample: 2002-2018

\begin{tabular}{ccccc}
\hline Variable & Coefficient & Std. Error & t-Statistic & Prob \\
\hline C & $23,238.34$ & 8785.367 & 2.645119 & 0.0202 \\
Unit Labour Cost & -246.8327 & 106.0150 & -2.328280 & 0.0367 \\
Imports & -1.482901 & 0.109883 & -13.49522 & 0.0000 \\
Exports & 1.156907 & 0.090761 & 12.74669 & 0.0000 \\
R-squared & 0.953527 & Mean dependent var & $-15,205.94$ \\
Adjusted R-squared & 0.942802 & S.D dependent var & $11,850.46$ \\
S.E of regression & 2834.162 & Akaike info criterion & 18.93920 \\
Sum squared resid & $1.04 \mathrm{E}+08$ & Schwarz criterion & 19.13525 \\
F-statistic & 88.91039 & Durbin-Watson stat & 0.964170 \\
Prob (F-statistic) & 0.000000 & &
\end{tabular}

BOP by 1.48 million EUR, and an increase of the exports by 1 million EUR increases the BOP by 1.15 million EUR, i.e. imports affect BOP more than exports do. Also, during recessions, an increase in domestic demand, relating to the financial cycle, may be more important for growth than placing emphasis on the current account balance [63], while the adoption of austerity measures can lead to slower economic growth [64]. Specifically, the effectiveness of fiscal policy on boosting total demand and stabilising economy decreases as public debt to GDP increases. In combination with the financial crisis, this led Greece in a vicious cycle of austerity and recession [45]. Figure 7 presents the decrease in consumer government expenditure from 50.1 billion EUR to 35.8 billion EUR, i.e. by $30 \%$, 


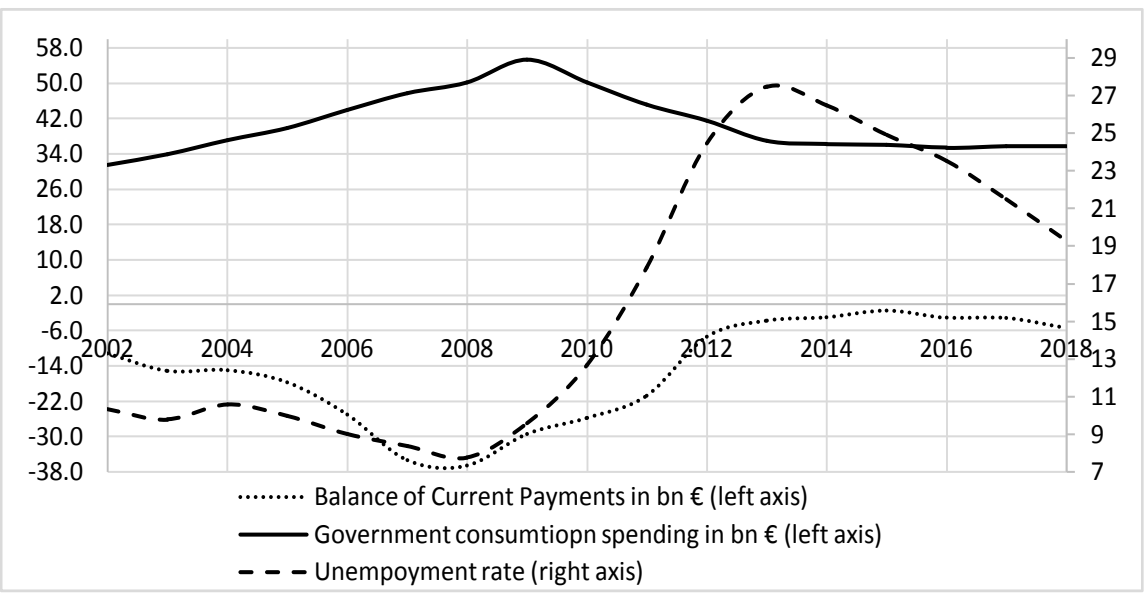

Figure 7. BOP, Government consumption spending and unemployment rate. Source: Bank of Greece and Eurostat.

accompanied by an improvement in current account balance by 30 billion EUR and by an increase of more than $20 \%$ in unemployment.

A major element of the Greek EAP was that it allowed Greece to become competitive enough to regain access to international capital markets, i.e. to improve its current account balance [65] and reforms in service and product market [66]. Figure 8 shows that the interest rate of government bonds moves in the opposite direction than the current account balance but with a 3 - 4-year time-delay.

\subsection{Twin Deficits}

European and international organisations have linked the issues with the current account balance directly to the fiscal deficit. Nonetheless, literature seems to be divided on this relationship.

Literature features two different views on the relationship between fiscal balance and current account balance. The first one is the positive correlation (Keynesian Twin Deficits) and the second one is the neutral (Ricardian Equivalence $)^{5}$. According to a study on Eurozone, results are not clear, as they do not validate either theory [67].

Current account deficit is related to fiscal deficit [68]. The extent of this relationship depends on how open an economy is [69].

A decrease in fiscal balance negatively affects the current account balance, whereas an increase in government spending as a result of borrowing has a more negative impact on the current account balance than taxation does [70].

Greece's persistent fiscal deficit is positively correlated to the current account deficit [71]. Figure 9 illustrates the development of twin deficits in Greece, while Table 7 shows how an increase in the fiscal balance by 1 million EUR would increase the current account balance by 0.96 million EUR, whereas fiscal balance can explain $36 \%$ of the BOP development.

${ }^{5}$ Research outcomes challenge the Ricardian theorem [84]. 


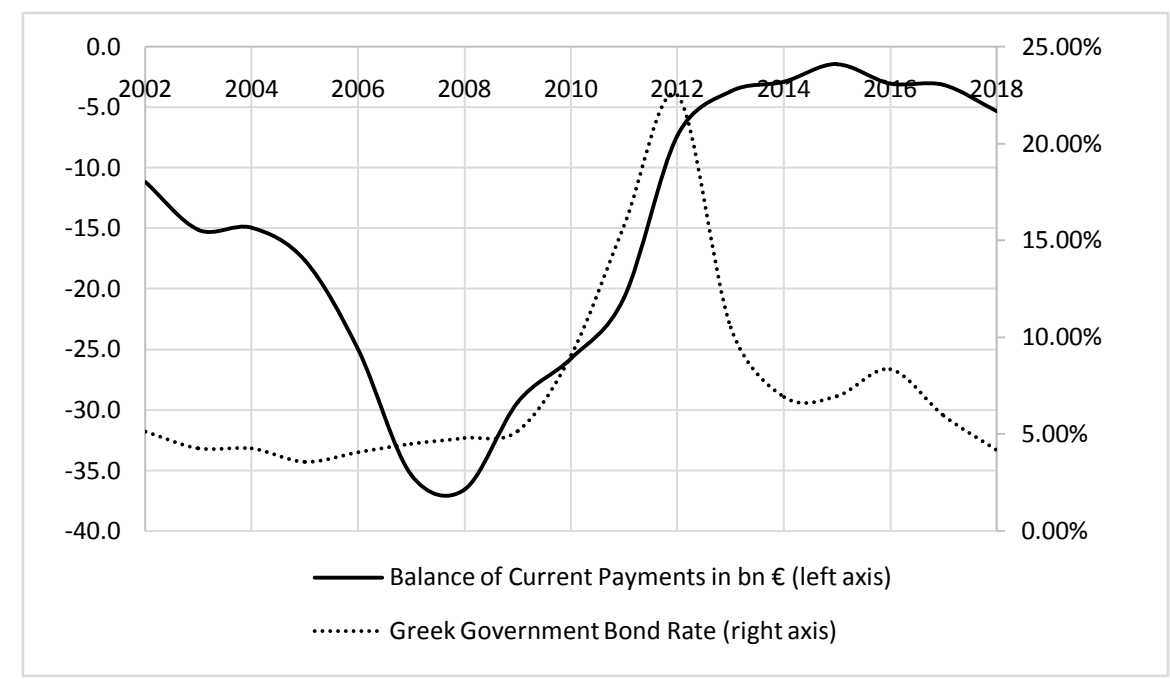

Figure 8. BOP and GGB rate. Source: Bank of Greece.

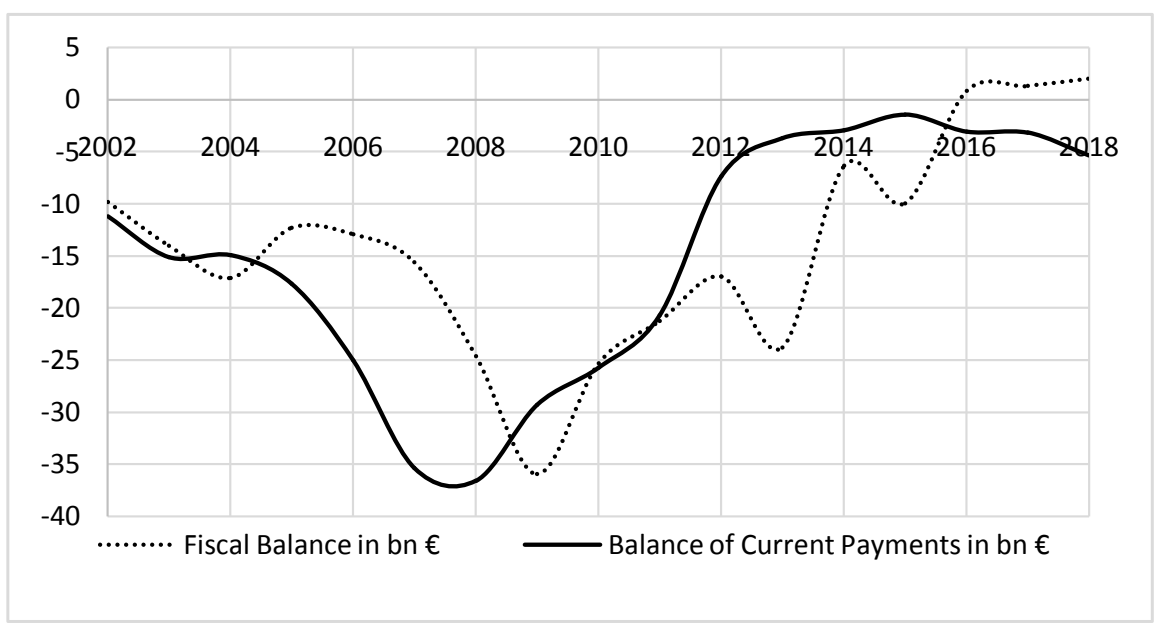

Figure 9. Fiscal balance and BOP. Source: Bank of Greece.

Table 7. Balance of payments regression.

Dependent Variable: Balance of Payments

Sample: 2002-2018

Included observations: 17 after adjustments

\begin{tabular}{ccccc}
\hline Variable & Coefficient & Std. Error & t-Statistic & Prob \\
\hline Fiscal Balance & 0.962033 & 0.131408 & 7.320949 & 0.0000 \\
R-squared & 0.367924 & Mean dependent var & -15205.94 \\
Adjusted R-squared & 0.367924 & S.D dependent var & 11850.46 \\
S.E of regression & 9421.495 & Akaike info criterion & 21.19640 \\
Sum squared resid & $1.42 \mathrm{E}+09$ & Schwarz criterion & 21.24541 \\
Log likehood & -179.1694 & Hannan Quinn criter. & 21.20127 \\
Durbin-Watson stat & 0.859989 & & \\
\hline
\end{tabular}


The most effective policy for increasing growth rate in Greece is to limit external imbalances, whereas policies aiming to decrease internal imbalances further boost slow growth rates [72]. Figure 10 shows that growth rate moves in the same direction as the current account balance but with a 3 - 4-year time-delay.

Different competitiveness levels among countries are not explained by the development of the trade balance, whereas austerity measures do not improve the current account balance [73]. The USA is a representative example, as they had twin deficits for years without facing competitiveness issues [74].

On the other hand, combining debt reforms and an increase in productivity will allow Greek economy to aim feasible primary surpluses without undermining growth, while investment and exports need to increase to bridge the gap arising from the lower government and private consumption [43]. Figure 11 and Figure 12 show that during implementation of the EAP, the unit labour cost ratio decreased from 105 to 101, private and government consumption decreased from 209 billion EUR to 155 billion EUR, and exports increased from 56 billion EUR to 69 billion EUR. Moreover, public debt was restructured through the sharp decrease of the lending interest rate from $4.06 \%$ to $1.61 \%$ and the extension of its maturity from 8.5 to 12.2 years, resulting in a decrease of the debt service cost from 11.6 billion EUR to 6.1 billion EUR per annum and in a primary surplus. Figure 12 illustrates the amount of FDI and PIP ${ }^{6}$. It is clear that investment dramatically decreased during the period 2007-2010, yet it has been recording an upward trend ever since.

Furthermore, high public debt does not constitute an inhibiting factor for growth rate, whereas econometric examples confirm that there is no positive correlation between the two variables, contrary to what Reinhart and Rogoff (2010A and 2010B) have supported, i.e. that high public debt slows down growth rate [75]. Table 8 shows that an increase in the public debt as a percentage of GDP decreases growth rate by $0.07 \%$, whereas public debt may only explain $37 \%$ of the growth rate development.

\subsection{Fiscal Multiplier}

Improving primary and fiscal balance ratios was a major objective set under the EAPs. Going from a fiscal deficit to a fiscal surplus during a recession translated into stabilising revenue while drastically reducing expenditure. In advanced economies, intense scheduled fiscal consolidation is linked to lower than expected growth, since this is a particularly strong relationship, both statistically and economically, especially at the beginning of a crisis. Fiscal multipliers being much higher than forecasted could provide an explanation [76]. To this end, more emphasis should have been placed in boosting growth and easing fiscal adjustment [77]. Figure 13 illustrates the development of the fiscal balance and

${ }^{6}$ Over $96 \%$ of the PIP and FDI sum corresponds to FDI, as PIP decreased from 716 million EUR in 2008 to 461 million EUR in 2018, while FDI remained stable at 27.1 billion EUR throughout the period 2008-2018. 


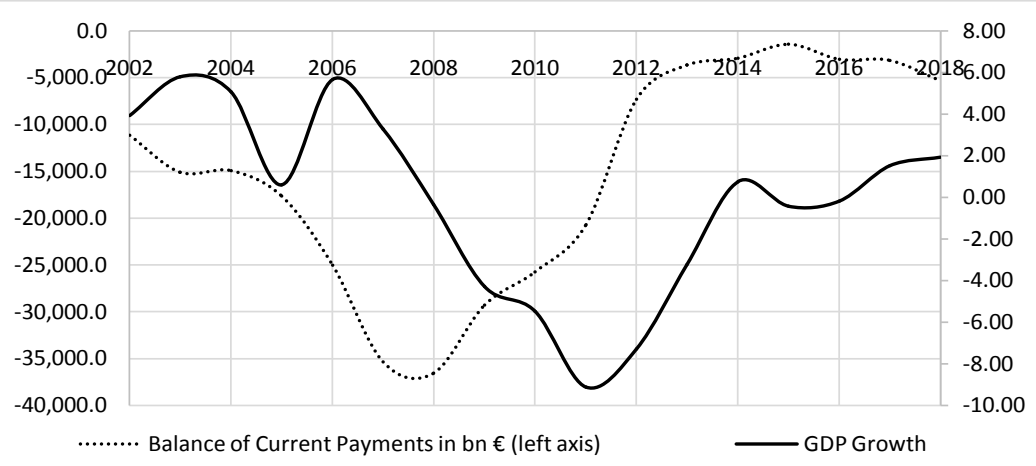

Figure 10. BOP and GDP growth. Source: Bank of Greece and Eurostat.

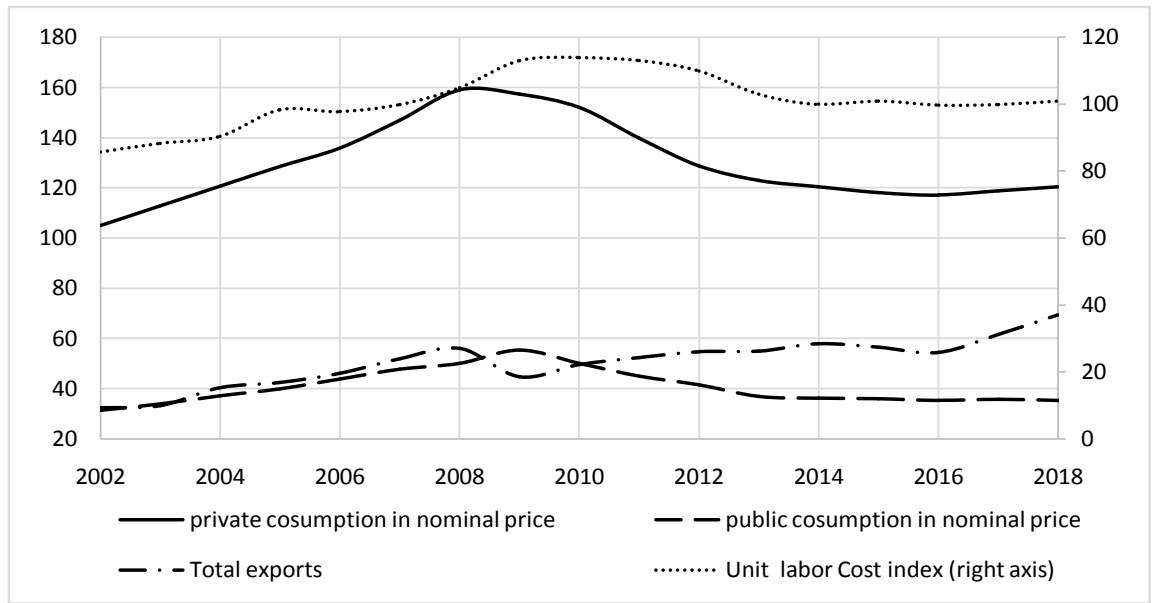

Figure 11. Private consumption, public consumption, total exports and ULC. Source: Bank of Greece and Eurostat.

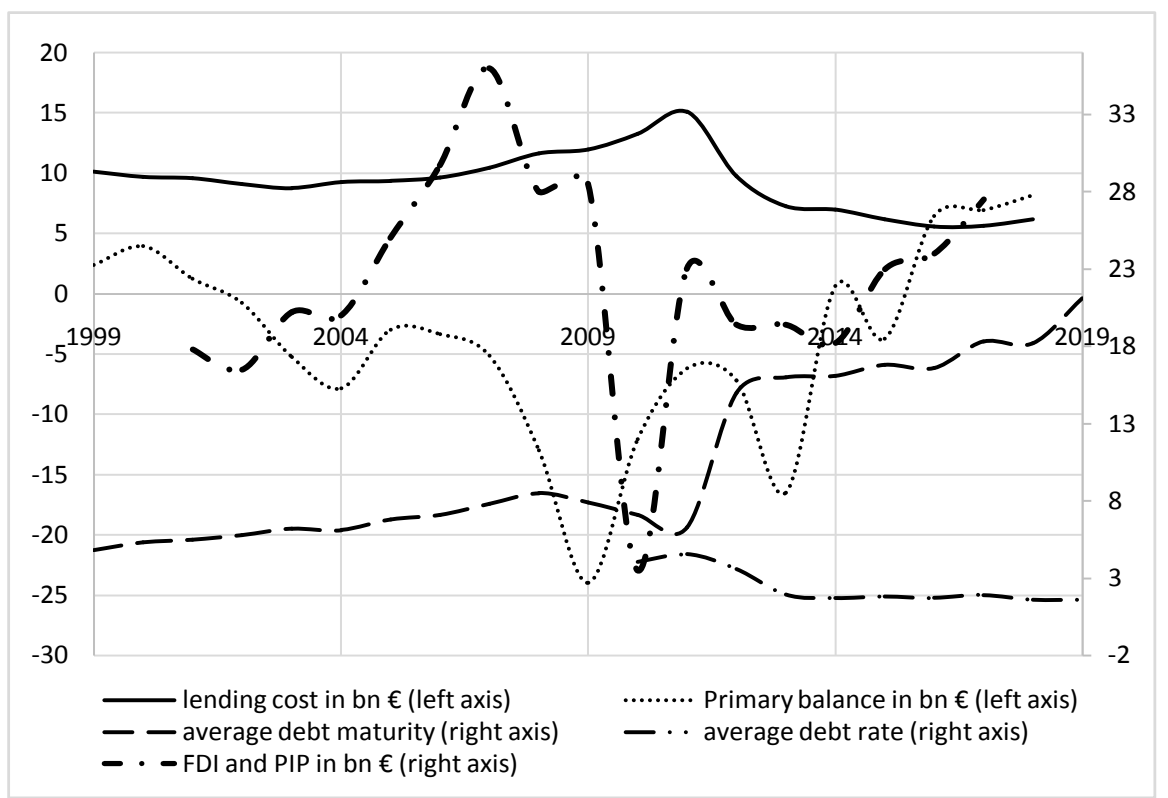

Figure 12. Lending cost, primary balance, average debt maturity and average debt rate. Source: Bank of Greece and Eurostat. 


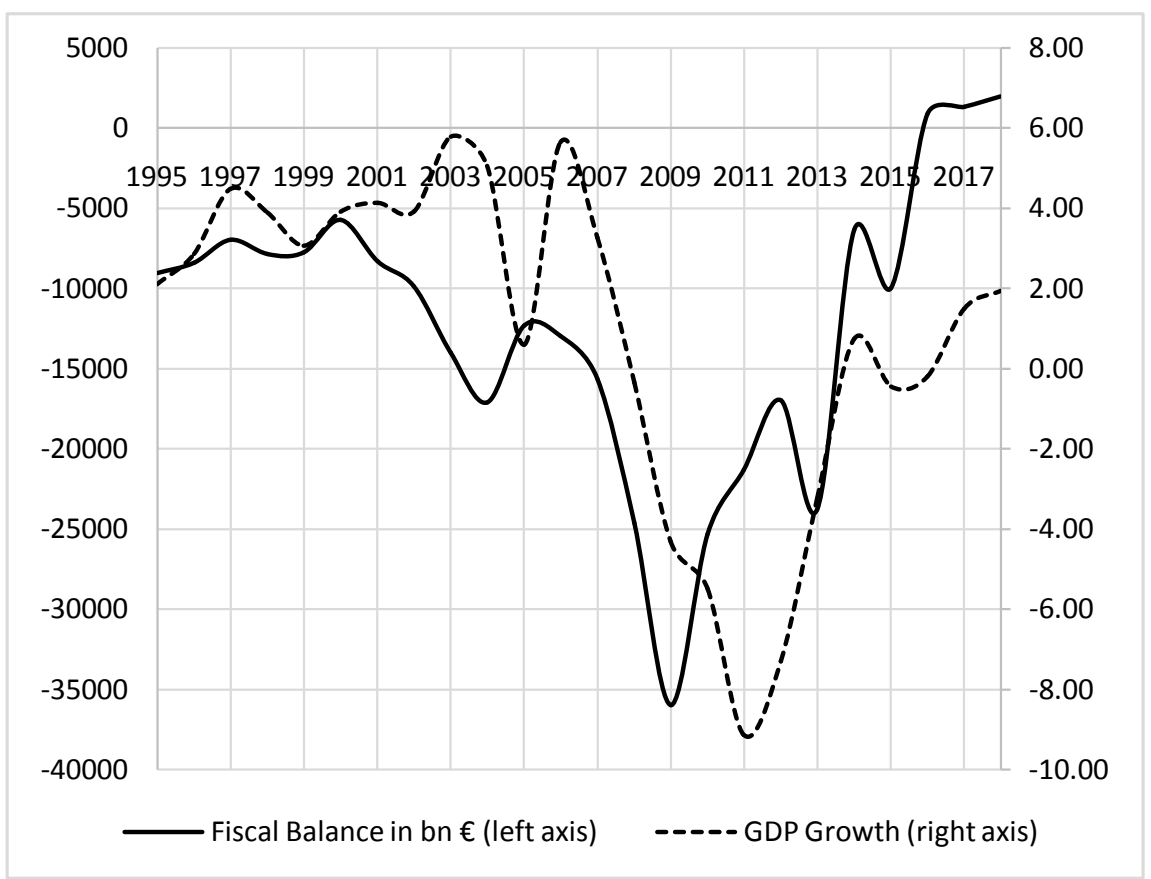

Figure 13. Fiscal balance and GDP growth rate between 1995 and 2018. Source: Bank of Greece and Eurostat.

Table 8. GDP Growth rate regression.

Dependent Variable: GDP Growth rate

Method: OLS

Sample: 1995-2018

Included observations: 24 after adjustments

\begin{tabular}{ccccc}
\hline Variable & Coefficient & Std. Error & t-Statistic & Prob \\
\hline C & 0.103738 & 0.026952 & 3.848940 & 0.0009 \\
Public Debt & -0.072682 & 0.020090 & -3.617891 & 0.0015 \\
R-squared & 0.373025 & Mean dependent var & 0.009375 \\
Adjusted R-squared & 0.344526 & S.D dependent var & 0.041103 \\
S.E of regression & 0.033278 & Akaike info criterion & -3.888203 \\
Sum squared resid & 0.024363 & Schwarz criterion & -3.790032 \\
Log likehood & 48.65844 & Hannan Quinn criter. & -3.862159 \\
F-statistic & 13.08913 & Durbin-Watson stat & 0.522219 \\
Prob (F-statistic) & 0.001524 & & \\
\hline
\end{tabular}

the growth rate. Fiscal balance noticeably improved during the crisis, going from a fiscal deficit of 35 billion EUR in 2009 to a fiscal surplus of 1.9 billion EUR in 2018, whereas growth rate followed the course of the fiscal balance with a 3 4-year delay. Table 9 illustrates the positive correlation between fiscal balance and growth rate. An increase in the fiscal balance by $1 \%$ of the GDP increases growth rate by $0.46 \%$, whereas the independent variable may only explain $21 \%$ of the course of the dependent variable. 
Table 9. GDP Growth rate regression.

Dependent Variable: GDP Growth rate

Method: OLS

Sample: $1995-2018$

Included observations: 24 after adjustments

\begin{tabular}{ccccc}
\hline Variable & Coefficient & Std. Error & t-Statistic & Prob \\
\hline C & 0.103738 & 0.026952 & 3.848940 & 0.0009 \\
Public Debt & -0.072682 & 0.020090 & -3.617891 & 0.0015 \\
R-squared & 0.373025 & Mean dependent var & 0.009375 \\
Adjusted R-squared & 0.344526 & S.D dependent var & 0.041103 \\
S.E of regression & 0.033278 & Akaike info criterion & -3.888203 \\
F-statistic & 13.08913 & Durbin-Watson stat & 0.522219 \\
Prob (F-statistic) & 0.001524 & & \\
\hline
\end{tabular}

Fiscal multiplier is higher during recession. Therefore, any change in government expenditure during the crisis has a more potent effect on the economy [78], whereas fiscal policy is more effective during a recession [79] [80]. Specifically, the fiscal multiplier is positive when government consumer spending increases and negative when revenue from higher taxation increases [81], as the increase in tax rates increases the recession [82]. It has been argued that in certain cases when income and capital taxation decreases to very low levels, the multiplier may be negative [83].

Figure 14 illustrates how the fiscal policy which was implemented during the crisis that stabilised government revenue and drastically cut expenditure from 123 billion EUR to 86 billion EUR, resulted in deeper recession and increased unemployment, at least in the short-term. Therefore, Greek governments could not implement an expansionary fiscal policy during the crisis to limit recession, but they implemented a procyclical fiscal policy that caused a deeper recession. According to Table 10 growth rate is negatively correlated to public debt, and total government revenue and expenditure, whereas it is positively correlated to the current account balance. Unit labour cost is positively correlated to the increase in public debt, and total government revenue and expenditure, whereas it is negatively correlated to fiscal balance ${ }^{7}$. BoP is positively correlated to public debt, total government revenue and fiscal balance, whereas it is negatively correlated to total government expenditure. FDI is negatively correlated to public debt and current account balance, whereas it is positively correlated to total government revenue and expenditure. Unemployment is positively correlated to all ratios under Pillar III. Six out of sixteen relationships are in conflict.

\section{Findings}

According to findings, the increase in public debt in Greece, during the crisis, related to the financial crisis, the increased NPLs and the rescue of the banks, ${ }^{7}$ The evidence shows how an increase in wage costs by 1 basis point decreases growth rate by $0.17 \%$, whereas wage costs explain only $25 \%$ of the growth rate. 


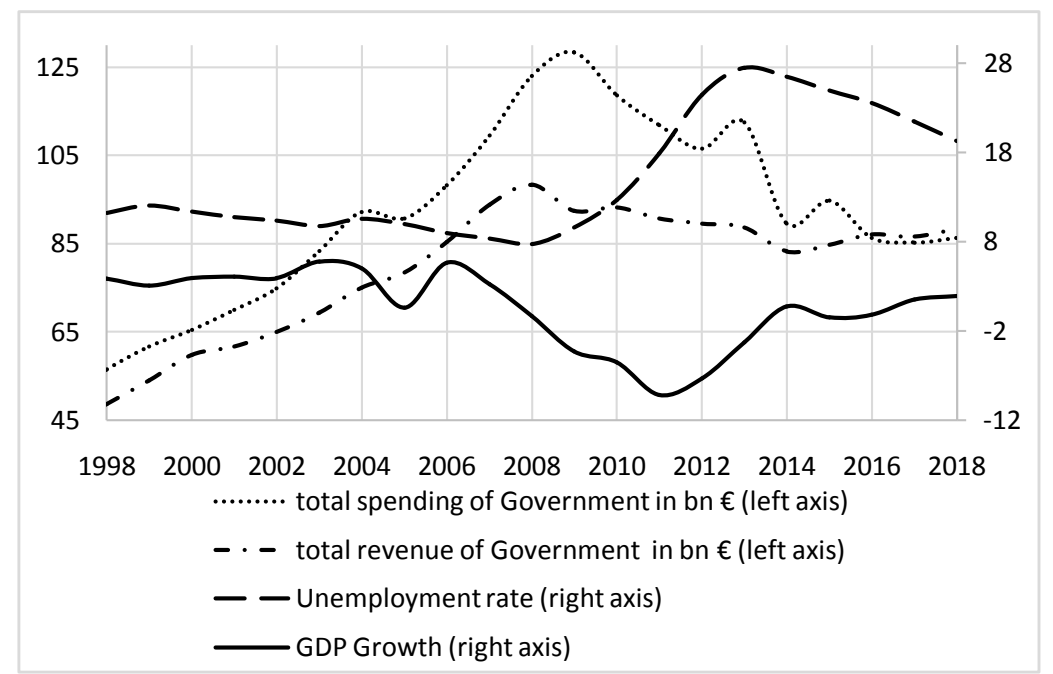

Figure 14. Total spending and revenue of Government, unemployment and GDP. Source: Bank of Greece and Eurostat.

Table 10. Indicators correlations.

\begin{tabular}{ccccc}
\hline & Public Debt Rate & $\begin{array}{c}\text { Total Gov. } \\
\text { Revenue }\end{array}$ & $\begin{array}{c}\text { Total Gov. } \\
\text { Spending }\end{array}$ & Fiscal Balance \\
\hline GDP Growth rate & -0.61088 & -0.53917 & -0.62363 & 0.528746 \\
ULC & 0.595384 & 0.942686 & 0.908952 & -0.5053 \\
Balance of payments & 0.687879 & 0.598849 & -0.6399 & 0.648579 \\
FDI & -0.1795 & 0.655747 & 0.550847 & -0.25438 \\
Unemployment rate & 0.882844 & 0.306894 & 0.08604 & 0.277458 \\
\hline
\end{tabular}

which is also confirmed by literature. Also, findings reveal a positive correlation between NPLs and unemployment (the increase in unemployment led to an increase in NPLs) and a negative correlation between NPLs, and GDP and inflation, which are also confirmed by literature. Additionally, the increase in the growth rate of new loans seems to cause a decrease in unemployment and an increase in the growth rate. These relationships are also confirmed by literature. Moreover, the current account balance moves in the opposite direction than the unit labour cost, as any increase in the ULC decreases BOP, while imports affect BOP more than exports do. Decreases in government consumer spending are positively correlated to improvements in $\mathrm{BOP}$ and negatively correlated to unemployment. These relationships are also confirmed by literature. Also, the findings confirm the theory of twin deficits in Greece, as improvements in the fiscal balance lead to improvements in the current account balance. Lastly, the findings reveal how the objective of achieving positive fiscal outcomes led to a deeper recession, as the fiscal multiplier tends to increase during recessions. This relationship is also confirmed by literature. All the above lead to the conclusion that the results of the PEA policies were expected, since the findings for the relationships between variables are overwhelmingly confirmed by literature. 


\section{Conclusions}

In this article, we examined whether PEA objectives were conflicting. We employed statistical tools to examine the relationships between 13 indicators, constituting the three pillars of the PEAs. This research is of important value as it illustrates how certain PEA objectives are indeed conflicting in the short-term, however, they become less conflicting in the medium-term. The findings of the research illustrate how a front-loaded PEA leads to a deeper recession and higher unemployment, and how greater fiscal and current account deficits increase the time required for a smooth adjustment, while a PEA spread out in time has fewer negative effects. Also, they illustrate that all major PEA objectives-pillars should be of equal importance. From all the above, it becomes clear that fiscal consolidation and financial stability policies are in conflict, as measures taken to rescue and stabilise the financial sector, such as recapitalising banks, increase public debt and render fiscal stability more difficult during a crisis.

Respectively, improving fiscal circumstances and achieving budgetary surpluses has a negative impact on growth rate and unemployment, at least in the short-term. In the medium term, the two policies become less conflicting. Therefore, it is apparent that parallel policies on fiscal consolidation and on promoting growth during a recession are conflicting, especially during the first years of implementing the reforms.

Finally, there are synergies between policies on financial stability and on promoting growth and competitiveness, as the decrease in NPLs, the increase in lending rate and the increase in bank deposits act complementary to the increase in employment and GDP growth.

As a final conclusion, we believe that EAPs could not have successfully implemented reforms across all three pillars at the same time, at least not in the short-term, whereas it is apparent that emphasis was placed on Pillar I, fiscal equilibrium, as this pillar features more satisfying results compared to the other two pillars.

\section{Conflicts of Interest}

The authors declare no conflicts of interest regarding the publication of this paper.

\section{References}

[1] Behram, J. (1987) The impact of Economic Adjustment Programs. In: Bell, D. and Reich, M., Eds., Health, Nutrition, and Economic Crises: Approaches to Policy in the Third World, Greenwood Publishing Group, Westport, CT, 103-123.

[2] Zattler, K. (1989) The Effects of Structural Adjustment Programmes. Intereconomics, 24, 282-289. https://doi.org/10.1007/BF02924735

[3] Thomson, M., Kentikelenis, A. and Stubbs T. (2017) Structural Adjustment Programmes Adversely Affect Vulnerable Populations: A Systematic-Narrative Review of Their Effect on Child and Maternal Health. Public Health Reviews, 38, 13. 
[4] Giannitsis, T. and Zografakis, T. (2018) Crisis Management in Greece. The Shaping of New Economic and Social Balances. Hans-Böckler-Stiftung, Düsseldorf.

[5] Mavridis, S. (2018) Greece's Economic and Social Transformation. Social Sciences, 7, 1-14. https://doi.org/10.3390/socsci7010009

[6] Kyriopoulos, I., Nikoloski, Z. and Mossialos, E. (2019) The Impact of the Greek Economic Adjustment Programme on Household Health Expenditure. Social Science \& Medicine, 222, 274-284. https://doi.org/10.1016/j.socscimed.2019.01.021

[7] IMF (2019) Greece: First Post-Program Monitoring Discussions-Press Release. Staff Report; and Statement by the Executive Director for Greece, IMF, Washington DC.

[8] European Commission (2018) Compliance Report ESM Stability Support Programme for Greece. European Commission, Brussels.

[9] European Commission (2019) Enhanced Surveillance Report-Greece, June 2019. European Commission, Brussels.

[10] OECD (2018) OECD Economic Surveys-Greece. OECD, Paris.

[11] European Commission (2019) Country Report Greece 2019 including an in-Depth Review on the Prevention and Correction of Macroeconomic Imbalances. European Commission, Brussels.

[12] Council Economic Advisors (2019) Economic Bulletin. COA, Athens.

[13] Mavroudeas, S. (2017) Troika's Economic Adjustment Programmes for Greece: Why Do They Systematically Fail? In: Marangos, J., Ed., The Internal Impact and External Influence of the Greek Financial Crisis, Palgrave Macmillan, London, 23-45. https://doi.org/10.1007/978-3-319-60201-1 3

[14] Frankel, J. and Schreger, J. (2013) Over-Optimistic Official Forecasts and Fiscal Rules in the Eurozone. Review of World Economics, 149, 247-272. https://doi.org/10.1007/s10290-013-0150-9

[15] Mavridakis, T., Dovas, D. and Bravou, S. (2018) Failure Factors of the Economic Adjustment Programme for Greece. In: Karasavvoglou, A., Goić, S., Polychronidou, P. and Delias, P., Eds., Economy, Finance and Business in Southeastern and Central Europe. Springer Proceedings in Business and Economics, Springer, Cham, 143-157. https://doi.org/10.1007/978-3-319-70377-0 10

[16] Botta, A. and Tori, D. (2015) A Critique to the Expansionary Austerity: Theoretical Weaknesses and Empirical Counter Evidence. Post Keynesian Economics Study Group, London.

[17] Frankel, J. (2015) The Euro Crisis: Where to from Here? Journal of Policy Modeling, 37, 428-444. https://doi.org/10.1016/j.jpolmod.2015.03.006

[18] Clemens, D. and Schoenwald, S. (2016) No Pain, No Gain? Economic Adjustment Programmes in Greece and Portugal. KFW Research, Frankfurt.

[19] Hardouvelis, G. and Gkionis, I. (2016) A Decade Long Economic Crisis: Cyprus versus Greece. Cyprus Economic Policy Review, 10, 3-40.

[20] Warmedinger, T., Checherita-Westphal, C. and De Cos, P. (2015) Fiscal Multipliers and Beyond. ECB, Frankfurt.

[21] Dollar, D. and Svensson, J. (2000) What Explains The Success or Failure of Structural Adjustment Programmes? The Economic Journal, 110, 894-917. https://doi.org/10.1111/1468-0297.00569

[22] Gechert, S. and Rannenberg, A. (2015) The Costs of Greece's Fiscal Consolidation. Vierteljahrshefte zur Wirtschaftsforschu, 84, 47-59.

[23] Pagoulatos, G. (2017) Greece: Searching for Light at the End of the Tunnel. Review 
of European Economic Policy, 52, 66-67.

https://doi.org/10.1007/s10272-017-0646-y

[24] Arestis, P. (2014) Coordination of Fiscal with Monetary and Financial Stability Policies Can Better Cure Unemployment. Review of Keynesian Economics, 3, 233-247. https://doi.org/10.4337/roke.2015.02.07

[25] Summers, L. and Pritchett, L. (1993) The Structural-Adjustment Debate. The American Economic Review, 83, 383-389.

[26] Heidhues, F. and Obare, G. (2011) Lessons from Structural Adjustment Programmes and their Effects in Africa. Quarterly Journal of International Agriculture, 50, 55-64.

[27] Toporowski, J. (1988) Togo: A Structural Adjustment that Destabilies Economic Growth. IDS Bulletin, 19, 17-23. https://doi.org/10.1111/j.1759-5436.1988.mp19001003.x

[28] Williams, G. (1994) Why Structural Adjustment Is Necessary and Why It Doesn't Work. Review of African Political Economy, 21, 214-225. https://doi.org/10.1080/03056249408704057

[29] Killick, T. (1990) Problems and Limitations of Adjustment Policies. Overseas Development Institute London, 1-58.

[30] Peabody, J. (1996) Economic Reform and Health Sector Policy: Lessons from Structural Adjustment Programs. Social Science \& Medicine, 43, 823-835. https://doi.org/10.1016/0277-9536(96)00127-X

[31] Khan, R., Nawaz, M. and Hussain, A. (2011) Impact Evaluation of Structural Adjustment Program: A Case of Pakistan. European Journal of Economics, Finance and Administrative Sciences, No. 29, 52-64.

[32] Rodrik, D. (1990) How Should Structural Adjustment Programs Be Designed? World Development, 18, 933-947. https://doi.org/10.1016/0305-750X(90)90077-B

[33] Bacha, E. and Feinberg, R. (1986) The World Bank and Structural Adjustment in Latin America. World Development, 14, 333-346. https://doi.org/10.1016/0305-750X(86)90073-2

[34] Herbst, J. (1990) The Structural Adjustment of Politics in Africa. World Development, 18, 949-958. https://doi.org/10.1016/0305-750X(90)90078-C

[35] Bradshaw, Y. and Huang, J. (1991) Intensifying Global Dependency: Foreign Debt, Structural Adjustment, and Third World Underdevelopment. The Sociological Quarterly, 32, 321-342. https://doi.org/10.1111/j.1533-8525.1991.tb00162.x

[36] Zaki, M. (2001) IMF-Supported Stabilization Programs and their Critics: Evidence from the Recent Experience of Egypt. World Development, 29, 1867-1883. https://doi.org/10.1016/S0305-750X(01)00074-2

[37] Corbo, V. and Fischer, S. (1995) Structural Adjustment, Stabilization and Policy Reform: Domestic and International Finance. Handbook of Development Economics, 3, 2845-2924. https://doi.org/10.1016/S1573-4471(95)30021-X

[38] Ghura, D., Calamitsis, E. and Basu, A. (1999) Adjustment and Growth in Sub-Saharan Africa. IMF, Washington DC. https://doi.org/10.5089/9781451847093.001

[39] World Bank (1986) Financing Adjustment with Growth in Sub-Saharan Africa, 1986-90. World Bank, Washington DC.

[40] Giavazzi, F. and Pagano, M. (2000) Can Severe Fiscal Contractions Be Expansionary? Tales of Two Small European Countries. NBER Macroeconomics Annual, 5, 
75-111. https://doi.org/10.1086/654131

[41] Lütz, S., Hilgers, S. and Schneider, S. (2019) Games Borrower Governments Play: The Implementation of Economic Adjustment Programmes in Cyprus and Portugal. West European Politics, 42, 1443-1463. ttps://doi.org/10.1080/01402382.2019.1583482

[42] Lütz, S. and Hilgers, S. (2019) When Overlapping Organisations Play Two-Level Games: IMF-EU Interaction in Credit Lending to Latvia and Greece. New Political Economy, 24, 299-312. https://doi.org/10.1080/13563467.2018.1443063

[43] Boafo-Arthur, K. (1999) Structural Adjustment Programs (SAPS) in Ghana: Interrogating NDC's Implementation. West Africa Review, 1, 1-19.

[44] Noorbakhsh, F. and Paloni, A. (2001) Structural Adjustment and Growth in Sub-Saharan Africa: The Importance of Complying with Conditionality. Economic Development and Cultural Change, 49, 479-509. https://doi.org/10.1086/452512

[45] Papadimos, L. (2011) Cyprus Economic Society the Sovereign Debt Crisis, Financial Stability and Fiscal Policy in The Euro Area. Ekonomia, 14, 108-118.

[46] Caruso, A., Reichlin, L. and Ricco, G. (2019) Financial and Fiscal Interaction in the Euro Area Crisis: This Time Was Different. European Economic Review, 119, 333-355. https://doi.org/10.1016/j.euroecorev.2019.08.002

[47] Bank of Greece (2012) Report on The Recapitalization and Restructuring of the Greek Banking Sector. Bank of Greece, Athens.

[48] Balteanu, I. and Erce, A. (2017) Linking Bank Crises and Sovereign Defaults: Evidence from Emerging Markets. ESM, Luxembourg. https://doi.org/10.2139/ssrn.2972818

[49] Mazreku, I., Morina, F., Misiri, F., Spiteri, J. and Grima, S. (2018) Determinants of the Level of Non-Performing Loans in Commercial Banks of Transition Countries. European Research Studies Journal, 11, 3-13. https://doi.org/10.35808/ersj/1040

[50] Konstantakis, K., Michaelides, P. and Vouldis, A. (2016) Non-Performing Loans (NPLs) in a Crisis Economy: Long-Run Equilibrium Analysis with a Real-Time VEC Model for Greece 2001-2015. MPRA, Munich. https://doi.org/10.1016/j.physa.2015.12.163

[51] Messai, A.S. and Jouin, F. (2013) Micro and Macro Determinants of Non-Performing Loans. International Journal of Economics and Financial Issues, 3, 852-860.

[52] Cucinell, D. (2015) The Impact of Non-Performing Loans on Bank Lending Behavior: Evidence from the Italian Banking Sector. Eurasian Journal of Business and Economics, 8, 59-71. https://doi.org/10.17015/ejbe.2015.016.04

[53] Bykova, A. and Pindyuk, O. (2019) Non-Performing Loans in Central and Southeast Europe. Vienna Institute for International Economic Studies, Vienna.

[54] Monokroussos, P., Thomakos, D. and Alexopoulos, T. (2016) High NPLs Ratio in Greece: Outcome of an Unprecedented Recession or the Lending Practices of Domestic Credit Institutions in the Pre-Crisis Era. Eurobank, Athens.

[55] Balgova, M., Plekhanov, A. and Skrzypinska, M. (2017) Reducing Non-Performing Loans: Stylized Facts and Economic Impact. Independent Researcher, London.

[56] Göçer, I. (2013) Relation between Bank Loans and Unemployment in the European Countries. European Academic Research, 1, 981-995.

[57] Bandyopadhyay, S., Dinopoulos, E. and Unel, B. (2016) Effects of Credit Supply on Unemployment and Inequality. Federal Reserve Bank of St. Louis Working Papers, St. Louis, MO. https://doi.org/10.20955/wp.2016.013 
[58] ECB (2012) Competitiveness and External Imbalances within the Euro Area. ECB, Frankfurt.

[59] Collignon, S. and Esposito, P. (2013) Unit Labour Costs and Capital Efficiency in the Euro Area: A New Competitiveness Indicator. Routledge, London.

[60] Collignon, S. (2013) Macroeconomic Imbalances and Competitiveness in the Euro Area. Transfer. European Review of Labour and Research, 19, 63-87. https://doi.org/10.1177/1024258912469467

[61] Böing, T. and Stadtmann, G. (2016) Competitiveness and Current Account Adjustments. European University Viadrina Frankfurt, Frankfurt.

[62] Gaulier, G. and Vicard, V. (2012) Current Account Imbalances in the Euro Area: Competitiveness or Demand Shock? Banque de France, Paris.

[63] Comunale, M. and Hesse, J. (2014) Current Account Imbalances in the Euro Area: Competitiveness or Financial Cycle? De Nederlandsche Bank NV, Amsterdam. https://doi.org/10.2139/ssrn.2509303

[64] Bianchi, F., Comin, D., Kung, H., Kind, T. and Matusche, A. (2019) Slow Recoveries through Fiscal Austerity. ZEW-Leibniz Centre for European Economic Research.

[65] Ioannides, Y.I. and Pissarides, C.A. (2015) Is the Greek Crisis One of Supply or Demand? Brookings Papers on Economic Activity, 2015, 349-373. https://doi.org/10.1353/eca.2015.0004

[66] Loukas, D. (2018) Realigning Competition Advocacy Priorities in the Context of Economic Adjustment Programmes: The Greek Case. In: Begović, B. and Popović, D., Eds., Competition Authorities in South Eastern Europe, Springer, Cham, 93-110. https://doi.org/10.1007/978-3-319-76644-7 6

[67] Forte, F. and Magazzino, C. (2015) Ricardian Equivalence and Twin Deficits Hypotheses in the Euro Area. Journal of Social and Economic Development, 17, 148-166. https://doi.org/10.1007/s40847-015-0013-4

[68] Kearney, C. and Monadjemi, M. (1990) Fiscal Policy and Current Account Performance: International Evidence on the Twin Deficits. Journal of Macroeconomics, 12, 197-219. https://doi.org/10.1016/0164-0704(90)90029-A

[69] Corsetti, G. and Müller, G. (2006) Twin Deficits: Squaring Theory, Evidence and Common Sense. Economic Policy, 21, 598-638.

https://doi.org/10.1111/j.1468-0327.2006.00167.x

[70] Mohammadi, H. (2004) Budget Deficits and the Current Account Balance: New Evidence from Panel Data. Journal of Economics and Finance, 28, 39-45. https://doi.org/10.1007/BF02761453

[71] Nikiforos, M., Carvalho, L. and Christian, S. (2015) “Twin Deficits” in Greece: In Search of Causality. Journal of Post Keynesian Economics, 38, 302-330. https://doi.org/10.1080/01603477.2015.1065675

[72] Soukiazis, E., Antunes, M. and Kostakis, I. (2018) The Greek Economy under the Twin-Deficit Pressure: A Demand Orientated Growth Approach. International Review of Applied Economics, 32, 215-236. https://doi.org/10.1080/02692171.2017.1338678

[73] Constantine, C. (2014) Rethinking the Twin Deficits. Journal of Australian Political Economy, 74, 57-80.

[74] Frankel, J. (2009) Eight Reasons We Are Given Not to Worry About the U.S. Deficits. World Bank, Washington DC.

[75] Herndon, T., Ash, M. and Pollin, R. (2014) Does High Public Debt Consistently 
Stifle Economic Growth? A Critique of Reinhart and Rogoff. Cambridge Journal of Economics, 38, 257-279. https://doi.org/10.1093/cje/bet075

[76] Blanchard, O. and Leigh, D. (2013) Growth Forecast Errors and Fiscal Multipliers. IMF, Washington DC. https://doi.org/10.3386/w18779

[77] Christodoulakis, N. (2013) From Grexit to Growth: On Fiscal Multipliers and How to End Recession in Greece. National Institute Economic Review, 224, 66-76. https://doi.org/10.1177/002795011322400106

[78] Auerbach, A. and Gorodnichenko, Y. (2011) Fiscal Multipliers in Recession and Expansion. National Bureau of Economic Research, Cambridge. https://doi.org/10.3386/w17447

[79] Ilzetzki, E., Mendoza, E. and Végh, C. (2013) How Big (Small?) Are Fiscal Multipliers? Journal of Monetary Economics, 2, 239-254. https://doi.org/10.1016/j.jmoneco.2012.10.011

[80] Auerbach, A. and Gorodnichenko, Y. (2012) Measuring the Output Responses to Fiscal Policy. American Economic Journal: Economic Policy, 4, 1-27. https://doi.org/10.1257/pol.4.2.1

[81] Monokroussos, P. and Thomakos, D. (2013) Greek Fiscal Multipliers Revisited Government Spending Cuts vs. Tax Hikes and the Role of Public Investment Expenditure. Eurobank, Athens.

[82] Arellano, C. and Bai, Y. (2016) Fiscal Austerity during Debt Crises. Federal Reserve Bank of Minneapolis, Minneapolis, MN. https://doi.org/10.21034/sr.525

[83] Eggertsson, G. (2010) NBER Macroeconomics Annual 2010. University of Chicago Press, Chicago, IL, 59-112. https://doi.org/10.1086/657529

[84] Douglas, B. (1987) Ricardian Equivalence: An Evaluation of Theory and Evidence. Macroeconomics Annual NBER No. 2330, 263-316.

[85] Vousinas, G. (2015) Recapitalization of the Greek Banking System \& The Fallacy of PSI: An Empirical Analysis with Future Prospects, Athens. https://doi.org/10.2139/ssrn.2546526

[86] Shen, Y. (2018) Labor Unemployment Insurance and Bank Loans. SSNR, New York. https://doi.org/10.2139/ssrn.3380402

[87] European Parliament (2018) Greece's Financial Assistance Programme-June 2018. European Parliament, Brussels.

[88] World Bank (2016) Bank Resolution and "Bail-in" in the EU: Selected Case Studies Pre and Post BRRD. World Bank, Vienna.

[89] Arslan, Y., Degerli, A. and Kabas, G. (2018) Unintended Consequences of Unemployment Insurance Benefits: The Role of Banks. Swiss Finance Institute Research Paper No. 19-44. https://doi.org/10.2139/ssrn.3280437

[90] Monokroussos, P. (2017) A Quantitative Assessment of the Agreement on Greece Reached at the Eurogroup of 15 June 2017. Eurobank, Athens. 